\title{
Synthesis of Substituted Dibenzo[a,d]azepines via a Base-Mediated Ring Expansion
}

\author{
U. Groth, L. Richter, and U. Schöllkopf * \\ Institut für Organische Chemie der Universität Göttingen, \\ Tammannstraße 2, W-3400 Göttingen, Germany
}

Received August 28, 1991

Key Words: Dibenzo $[a, d]$ azepines / Norcaradienes, intermediates in ring expansion reactions

Substituted dibenzoazepines $\mathbf{5}$ and $\mathbf{1 0}$ were synthesized in three steps by starting from acridine (6). The key step of the synthesis is a base-mediated ring expansion reaction of the mesylates 1.

Recently, we described a novel, base-mediated ring expansion of 2,5-dihydropyrazines to $2 H$-1,4-diazepines and of benzodihydroarenes to benzocycloheptene derivatives ${ }^{[1,2]}$. Consequently, we were interested in the preparation of the mesylates $\mathbf{1}$, which should undergo a similar ring expansion reaction upon treatment with potassium tert-butoxide in DMSO to afford the dibenzoazepines 5.<smiles>[R]CC1([R])c2ccccc2N([TlH])c2ccccc21</smiles><smiles>[13CH3]</smiles>

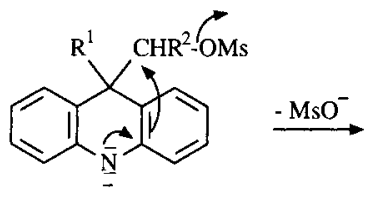
2

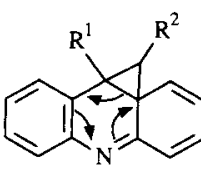

3<smiles>[R]C1=C([R])c2ccccc2Nc2ccccc21</smiles>

Substituted dibenzoazepines such as compounds 5 warrant the attention as intermediates in the synthesis of antiepileptic and antipsychotic drugs like carbamazepine ${ }^{[3]}$ and opipramol $^{[4]}$. The amino alcohols 9 , precursors of the mesylates 1 , were synthesized in three steps by starting from acridine (6).

After nucleophilic addition of methyllithium or phenyllithium to acridine (6), the resulting anions were trapped with benzyl bromide to afford the 9,10-dihydroacridines 7 . The most efficient method for the preparation of the amino alcohols $9 \mathbf{a}-\mathbf{b}$ from the dihydroacridines 7 proved to be the alkylation of the lithiated dihydroacridines 7 with benzyl

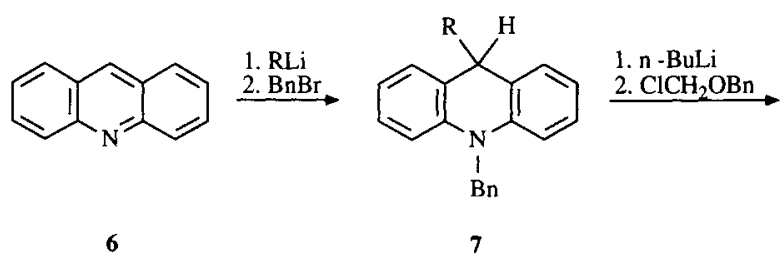<smiles>[R]C1(CO)c2ccccc2N(Cc2ccccc2)c2ccccc2C1([R])CO</smiles><smiles>OC(c1ccccc1)C(c1ccccc1)c1ccccc1N(Cc1ccccc1)c1cccc2c1N(Cc1ccccc1)c1ccccc1C2(c1ccccc1)c1ccccc1</smiles>

chloromethyl ether, followed by hydrogenolytic removal of both benzyl groups.

The amino alcohol 9c was prepared in a different manner. After lithiation of the 9,10-dihydroacridine 7 and addition of the lithiated species to benzaldehyde, the alcohol $8 \mathrm{c}$ was isolated in $87 \%$ yield. The $N$-benzyl group of $8 \mathrm{c}$ could not be removed by hydrogenolysis, probably due to partial cleavage of $8 \mathbf{c}$ to benzaldehyde and $7 \mathbf{b}$ and subsequent formation of byproducts which polluted the catalyst. The sensitive amino alcohol 9c was obtained by debenzylation of $8 \mathrm{c}$ with lithium in liquid ammonia/THF. The mesylates 1 were prepared by reaction of the amino alcohols 9 with methanesulfonyl chloride and triethylamine.

Upon treatment with potassium tert-butoxide, the mesylate 1 a was converted into the exo-methylidene compound 10 as the single product. A cyclic transition state required for a transannular $\left[1_{s}, 5_{s}\right]$-sigmatropic hydrogen shift includ- 
ing the methyl group is extremely disfavoured due to sterical reasons. Thus, compound $\mathbf{1 0}$ should be formed via deprotonation of the intermediate $\mathbf{4 a}$ at the $10-\mathrm{CH}_{3}$ group.

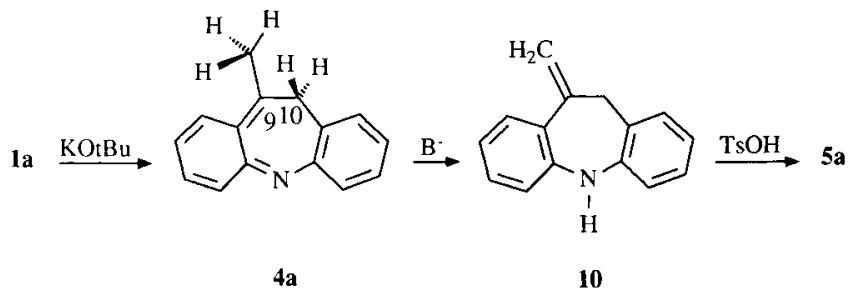

Evidently, the different reaction pathway of the intermediate 4 a compared to the all-carbon analogue (see ref. ${ }^{[1]}$ ) is caused by the nitrogen atom in the 5-position which facilitates deprotonation by inductive and mesomeric effects and which disfavours the $[1,5$,$] -sigmatropic hydrogen shift by$ enhancement of the LUMO energy of the 1-azadiene system $^{[5]}$.

Due to steric and stereoelectronic reasons, deprotonation at the $10-\mathrm{CH}_{3}$ group is favoured compared with deprotonation at the $11-\mathrm{CH}_{2}$ group. Compound $\mathbf{1 0}$ was isomerized quantitatively to the dibenzoazepine $\mathbf{5 a}$ with catalytical amounts of $p$-toluenesulfonic acid in refluxing toluene.

Upon treatment with potassium tert-butoxide in DMSO, the mesylate $\mathbf{1} \mathbf{b}$ was converted into the expected 9-phenyldibenzoazepine $\mathbf{5} \mathbf{b}$. The dibenzoazepine $\mathbf{5} \mathbf{b}$ might be formed either by a $[1,5$,$] -sigmatropic hydrogen shift or by depro-$ tonation at the $11-\mathrm{CH}_{2}$ group.

Which of the two possible pathways prevails could not be determined by the available experimental data. Due to the facile $\mathrm{H}-\mathrm{D}$ exchange at the nitrogen atom, deuteration at the $\mathrm{CH}_{2} \mathrm{OMs}$ group of the precursor $\mathbf{1} \mathbf{b}$ is not suitable for proving the mechanism for the formation of compound $5 \mathbf{b}$.

After treatment of the mesylate 1c with potassium tertbutoxide in DMSO, 9-phenylacridine was isolated in $40 \%$ yield due to a fragmentation of the anion $2 \mathrm{c}$. The higher stability of benzaldehyde compared with formaldehyde seems to favour the fragmentation of the anion $\mathbf{2 c}$.

Financial support by the Stiftung Volkswagenwerk and the Deutsche Forschungsgemeinschaft is gratefully acknowledged.

\section{Experimental}

All reactions with organometallic reagents were performed in anhydrous solvents under dry nitrogen. - Starting materials were distilled or recrystallized before use. $-{ }^{1} \mathrm{H}-\mathrm{NMR}$ and ${ }^{13} \mathrm{C}-\mathrm{NMR}$ spectra: Varian XL 80, XL 200 and VXR 200. Chemical shifts are given in values relative to TMS. - IR-spectra: Perkin-Elmer 298. - Low-pressure chromatography: Silica gel, Baker, $30-60 \mu \mathrm{m}$. - Melting points are uncorrected.

Preparation of the Dihydroacridines 7. - General Procedure: To a stirred solution of acridine $(1.79 \mathrm{~g}, 10.0 \mathrm{mmol})$ in diethyl ether $(60 \mathrm{ml})$, methyllithium or phenyllithium in diethyl ether $(1.6 \mathrm{~N}$, $6.9 \mathrm{ml}, 11.0 \mathrm{mmol}$ ) was added at $0^{\circ} \mathrm{C}$. After stirring for $2 \mathrm{~h}$ at $25^{\circ} \mathrm{C}$, the solution was cooled to $0 \mathrm{C}$ and benzyl bromide $(1.88 \mathrm{~g}, 11.0$ mmol) was added dropwise. Stirring was continued for $2 \mathrm{~h}$ at $25^{\circ} \mathrm{C}$, and the solvent was removed in vacuo. The crude product was dissolved in ethyl acetate $(60 \mathrm{ml})$ and the resulting solution was washed with $10 \% \mathrm{NaHCO}_{3}(30 \mathrm{ml})$ and a saturated $\mathrm{NaCl}$ solution $(30 \mathrm{ml})$. The united aqueous layers were reextracted with ethyl acetate $(30 \mathrm{ml})$, and the combined organic layers were dried with $\mathrm{MgSO}_{4}$. The crude products were purified by recrystallization from ethyl acetate.

10-Benzyl-9-methyl-9,10-dihydroacridine (7a): $2.40 \mathrm{~g}(84 \%)$ of $7 \mathrm{a}$ was obtained. - M.p. $151^{\circ} \mathrm{C}$. - IR $(\mathrm{KBr}): \tilde{v}=1580 \mathrm{~cm}^{-1}$ $(\mathrm{C}=\mathrm{C}) .-{ }^{1} \mathrm{H}$ NMR $\left(\mathrm{CDCl}_{3}\right): \delta=1.37\left(\mathrm{~d}, J=8 \mathrm{~Hz} ; 3 \mathrm{H}, \mathrm{CH}_{3}\right)$, $4.08(\mathrm{q}, J=8 \mathrm{~Hz} ; 1 \mathrm{H}, 9-\mathrm{H}), 5.14\left(\mathrm{~s} ; 2 \mathrm{H}, \mathrm{NCH}_{2}\right), 6.52-7.31(\mathrm{~m}$; $13 \mathrm{H}$, arom. $\mathrm{H}) .-{ }^{13} \mathrm{C} \mathrm{NMR}\left(\mathrm{CDCl}_{3}\right): \delta=26.67\left(\mathrm{CH}_{3}\right), 37.69(9-$ $\mathrm{CH}), 50.52\left(\mathrm{NCH}_{2}\right), 113.12,120.75,126.19,126.82,127.69$ and 128.69 (arom. CH), 128.52, 136.96 and 140.71 (arom. C). - MS (70 eV): $m / z(\%)=285(30)\left[\mathrm{M}^{+}\right], 270(73)\left[\mathrm{M}^{+}-\mathrm{CH}_{3}\right], 91(100)$ $\left[\mathrm{C}_{7} \mathrm{H}_{7}^{+}\right]$.

$$
\begin{array}{ll}
\mathrm{C}_{21} \mathrm{H}_{19} \mathrm{~N} \text { (285.4) } & \text { Calcd. C 88.38 H } 6.71 \\
& \text { Found C 88.25 H } 6.86
\end{array}
$$

10-Benzyl-9-phenyl-9,10-dihydroacridine (7b): $2.85 \mathrm{~g}(82 \%)$ of $7 \mathbf{b}$ was obtained. - M.p. $137^{\circ} \mathrm{C}$ - IR (KBr): $\tilde{v}=1580 \mathrm{~cm}^{-1}$ $(\mathrm{C}=\mathrm{C}) .-{ }^{1} \mathrm{H}$ NMR $\left(\mathrm{CDCl}_{3}\right): \delta=5.13\left(\mathrm{~s} ; 2 \mathrm{H}, \mathrm{NCH}_{2}\right), 5.26(\mathrm{~s} ; 1 \mathrm{H}$, 9-H), $6.56-7.25\left(\mathrm{~m} ; 18 \mathrm{H}\right.$, arom. H). $-{ }^{13} \mathrm{C} \mathrm{NMR}\left(\mathrm{CDCl}_{3}\right): \delta=$ $48.10(9-\mathrm{CH}), 50.73\left(\mathrm{NCH}_{2}\right), 113.49,120.82,126.19,126.32,126.85$, 127.31, 127.53, 128.48, 128.72 and 129.06 (arom. CH), 126.24, 136.96, 141.02 and 146.27 (arom. C). - MS $(70 \mathrm{eV}): m / z(\%)=347(52)$ $\left[\mathrm{M}^{+}\right], 270(84)\left[\mathrm{M}^{+}-\mathrm{C}_{6} \mathrm{H}_{5}\right], 256(43)\left[\mathrm{M}^{+}-\mathrm{C}_{7} \mathrm{H}_{7}\right], 91(100)$ $\left[\mathrm{C}_{7} \mathrm{H}_{7}^{+}\right]$.

$$
\begin{array}{ll}
\mathrm{C}_{26} \mathrm{H}_{21} \mathrm{~N}(347.5) & \text { Calcd. C } 89.88 \text { H } 6.09 \\
& \text { Found C 89.96 H } 6.17
\end{array}
$$

Alkylation of the 9,10-Dihydroacridines 7. - Compounds 8. General Procedure: A solution of $n$-butyllithium in hexane $(1.6 \mathrm{~N}$, $5.5 \mathrm{ml}, 8.8 \mathrm{mmol}$ ) was added at $-70^{\circ} \mathrm{C}$ to a stirred solution of the dihydroacridine $7 \mathrm{a}(2.28 \mathrm{~g}, 8.0 \mathrm{mmol})$ in THF $(60 \mathrm{ml})$ and TMEDA $(4.09 \mathrm{~g}, 35.2 \mathrm{mmol})$ or $7 \mathrm{~b}(2.78 \mathrm{~g}, 8.0 \mathrm{mmol})$ in THF $(60 \mathrm{ml})$, respectively. The solution was allowed to warm up to $0^{\circ} \mathrm{C}$ and stirred for $30 \mathrm{~min}$ at $0 \mathrm{C}$. Then it was cooled to $-70^{\circ} \mathrm{C}$, and benzyl chloromethyl ether $(1.38 \mathrm{~g}, 8.8 \mathrm{mmol})$ was added dropwise. Stirring was continued for $16 \mathrm{~h}$ at $-70^{\circ} \mathrm{C}$, concentrated $\mathrm{NH}_{3}(1 \mathrm{ml})$ was added, and the solvent was removed in vacuo. The residue was dissolved in diethyl ether $(100 \mathrm{ml})$ and washed with $5 \% \mathrm{NaHCO}_{3}(30 \mathrm{ml})$ and a saturated $\mathrm{NaCl}$ solution $(30 \mathrm{ml})$. The united aqueous layers were extracted with dicthyl ether $(30 \mathrm{ml})$, the combined organic layers were dried with $\mathrm{MgSO}_{4}$, and the solvent was removed in vacuo. The crude product was purified by column filtration (petroleum ether/diethyl ether, 50:1) and recrystallization from ethyl acetate.

10-Benzyl-9-benzyloxymethyl-9-methyl-9,10-dihydroacridine (8a): $2.11 \mathrm{~g}(65 \%)$ of 8 a was obtained. $-R_{\mathrm{f}}=0.15$. - M.p. $126^{\circ} \mathrm{C}$. IR $(\mathrm{KBr}): \tilde{v}=1580 \mathrm{~cm}^{-1}(\mathrm{C}=\mathrm{C}) .-{ }^{1} \mathrm{H}$ NMR $\left(\mathrm{CDCl}_{3}\right): \delta=1.84$ $\left(\mathrm{s} ; 3 \mathrm{H}, \mathrm{CH}_{3}\right), 3.46$ (s; $2 \mathrm{H}, \mathrm{CH}_{2} \mathrm{OBn}$ ), 4.26 (s; $\left.2 \mathrm{H}, \mathrm{OCH}_{2} \mathrm{Ph}\right), 5.09$ (s; $\left.2 \mathrm{H}, \mathrm{NCH}_{2}\right), 6.68-7.46(\mathrm{~m} ; 18 \mathrm{H}$, arom. $\mathrm{H}) .-{ }^{13} \mathrm{C} \mathrm{NMR}\left(\mathrm{CDCl}_{3}\right)$ : $\delta=21.54\left(\mathrm{CH}_{3}\right), 41.24(\mathrm{C}-9), 51.04\left(\mathrm{NCH}_{2}\right), 72.86\left(\mathrm{CH}_{2} \mathrm{OBn}\right), 76.83$ $\left(\mathrm{OCH}_{2} \mathrm{Ph}\right), 113.12,120.42,126.04,126.14,126.72,127.10,127.18$, 128.01 and 128.61 (arom. CH), 127.85, 136.87, 138.52 and 141.05 (arom. C). - MS $(70 \mathrm{eV}): m / z(\%)=405(3)\left[\mathrm{M}^{+}\right], 284(100)$ $\left[\mathrm{M}^{+}-\mathrm{CH}_{2} \mathrm{OBn}\right], 91(59)\left[\mathrm{C}_{7} \mathrm{H}_{7}^{+}\right]$.

$$
\begin{aligned}
& \mathrm{C}_{29} \mathrm{H}_{27} \mathrm{NO} \text { (405.5) Calcd. C } 85.89 \mathrm{H} 6.71 \\
& \text { Found C } 85.76 \text { H } 6.89
\end{aligned}
$$

10-Benzyl-9-benzyloxymethyl-9-phenyl-9,10-dihydroacridine $(\mathbf{8 b})$ : $2.92 \mathrm{~g}(78 \%)$ of $8 \mathbf{b}$ was obtained. $-R_{\mathrm{f}}=0.13$. - M.p. $144 \mathrm{C}$. IR $(\mathrm{KBr}): \tilde{v}=1580 \mathrm{~cm}^{-1}(\mathrm{C}=\mathrm{C}) .-{ }^{1} \mathrm{H}$ NMR $\left(\mathrm{CDCl}_{3}\right): \delta=3.93$ (s; $2 \mathrm{H}, \mathrm{CH}_{2} \mathrm{OBn}$ ), 4.34 (s; $\left.2 \mathrm{H}, \mathrm{OCH}_{2} \mathrm{Ph}\right), 5.03$ (s; $2 \mathrm{H}, \mathrm{NCH}_{2}$ ), $6.70-7.42\left(\mathrm{~m} ; 23 \mathrm{H}\right.$, arom. H). $-{ }^{13} \mathrm{C} \mathrm{NMR}\left(\mathrm{CDCl}_{3}\right): \delta=51.00$ $\left(\mathrm{NCH}_{2}\right), 51.46(\mathrm{C}-9), 73.00\left(\mathrm{CH}_{2} \mathrm{OBn}\right), 74.43\left(\mathrm{OCH}_{2} \mathrm{Ph}\right), 112.81$, $120.02,126.16,126.84,127.17,127.29,127.31,127.73,128.07,128.71$ 
and 130.00 (arom. CH), 128.15, 137.04, 138.30, 140.92 and 146.45 (arom. C). - MS $(70 \mathrm{eV}): m / 2(\%)=467(2)\left[\mathrm{M}^{+}\right], 346(100)$ $\left[\mathrm{M}^{+}-\mathrm{CH}_{2} \mathrm{OBn}\right], 255(6)\left[\mathrm{M}^{+}-\mathrm{C}_{7} \mathrm{H}_{7}-\mathrm{CH}_{2} \mathrm{OBn}\right], 91(70)$ $\left[\mathrm{C}_{7} \mathrm{H}_{7}^{+}\right]$.

$$
\begin{array}{ll}
\mathrm{C}_{34} \mathrm{H}_{29} \mathrm{NO}(467.6) & \text { Calcd. C } 87.33 \text { H } 6.25 \\
& \text { Found C } 87.25 \text { H } 6.39
\end{array}
$$

10-Benzyl-9-(1-hydroxybenzyl)-9-phenyl-9,10-dihydroacridine $(\mathbf{8 c})$ : The dihydroacridine $7 \mathbf{b}(2.78 \mathrm{~g}, 8.0 \mathrm{mmol})$ was lithiated as described above. To the stirred solution of lithiated $7 \mathbf{b}$, benzaldehyde $(0.93 \mathrm{~g}, 8.8 \mathrm{mmol})$ was added dropwise at $-70^{\circ} \mathrm{C}$, and stirring was continued for $15 \mathrm{~min}$. Then a solution of acetic acid $(0.60 \mathrm{~g}$, $10.0 \mathrm{mmol})$ in THF $(5 \mathrm{ml})$ was added, and the amount of solvent was reduced to $30 \mathrm{ml}$ in vacuo. The residue was dissolved in ethyl acetate $(120 \mathrm{ml})$ and washed with $10 \% \mathrm{NaHCO}_{3}(50 \mathrm{ml})$ and a saturated $\mathrm{NaCl}$ solution $(50 \mathrm{ml})$. The united aqueous layers were reextracted with $50 \mathrm{ml}$ ethyl acetate, and the combined organic layers were dried with $\mathrm{MgSO}_{4}$. The amount of solvent was reduced in vacuo to $25 \mathrm{ml}$, and the solution was kept at $0^{\circ} \mathrm{C}$ for $16 \mathrm{~h} ; 3.16 \mathrm{~g}$ $(87 \%)$ of alcohol $8 \mathbf{c}$ was obtained. - M.p. $206^{\circ} \mathrm{C}$. - IR (KBr): $\tilde{v}=3520(\mathrm{OH}), 1580 \mathrm{~cm}^{-1}(\mathrm{C}=\mathrm{C}) .-{ }^{1} \mathrm{H}$ NMR $\left(\mathrm{CDCl}_{3}\right): \delta=2.38$ (d, $J=8 \mathrm{~Hz} ; 1 \mathrm{H}, \mathrm{OH}), 3.92$ and $4.16\left(\mathrm{AB}\right.$ system, $J_{\mathrm{AB}}=18 \mathrm{~Hz}$; $\left.2 \mathrm{H}, \mathrm{NCH}_{2}\right), 5.48[\mathrm{~d}, J=8 \mathrm{~Hz} ; 1 \mathrm{H}, \mathrm{CH}(\mathrm{OH}) \mathrm{Ph}], 6.10-7.95(\mathrm{~m}$; $23 \mathrm{H}$, arom. H). $-{ }^{13} \mathrm{C} \mathrm{NMR}\left(\mathrm{CDCl}_{3}\right): \delta=51.91\left(\mathrm{NCH}_{2}\right), 56.72(\mathrm{C}-$ 9), 78.78 (CHOH), 112.54, 112.68, 119.47, 119.95, 125.72, 126.10, $126.38,126.81,127.26,127.39,127.59,127.73,128.05,128.72,130.08$ and 132.01 (arom. CH) $124.15,128.56,137.36,140.77,140.88,142.28$ and 148.12 (arom. C). - MS $(70 \mathrm{eV}): m / z(\%)=435(1)\left[\mathrm{M}^{+}-\right.$ $\left.\mathrm{H}_{2} \mathrm{O}\right], 347(100)\left[\mathrm{M}^{+}-\mathrm{PhCHO}\right], 254(57)\left[\mathrm{M}^{+}-\mathrm{PhCHO}-\right.$ $\left.\mathrm{C}_{7} \mathrm{H}_{7}\right], 91(54)\left[\mathrm{C}_{7} \mathrm{H}_{7}^{+}\right]$.

$$
\begin{array}{ll}
\mathrm{C}_{33} \mathrm{H}_{27} \mathrm{NO} \text { (453.6) } & \text { Calcd. C 87.39 H } 6.00 \\
& \text { Found C 87.27 H } 6.12
\end{array}
$$

Hydrogenation of the Benzyl Ethers $8 \mathbf{a}$ and $8 \mathbf{b}$. - Compounds $9 \mathbf{a}$ and $9 \mathrm{~b}$. - General Procedure: 5.1 or $6.2 \mathrm{mmol}$ of the benzyl ethers $\mathbf{8 a}$ or $\mathbf{8 b}$ was dissolved in ethyl acetate $(90 \mathrm{ml})$, and ethanol $(90 \mathrm{ml})$ and $\mathrm{Pd} / \mathrm{C}(1.2 \mathrm{~g}, \mathrm{Pd}$ content $10 \%)$ were added. The apparatus was flushed with hydrogen, and the vigorously stirred solution was refluxed for $16 \mathrm{~h}$ at 1 bar. The solution was cooled to room temp., the catalyst filtered off, the solvent removed in vacuo and the residue purified by flash chromatography.

9-Hydroxymethyl-9-methyl-9,10-dihydroacridine (9a): From $2.07 \mathrm{~g}$ $(5.1 \mathrm{mmol})$ of $8 \mathbf{a}, 0.85 \mathrm{~g} \mathrm{(74 \% )}$ of $9 \mathbf{a}$ was obtained as a light yellow oil after flash chromatography on silica gel $(80 \mathrm{~g})$. $-R_{\mathrm{f}}$ (diethyl ether/petroleum ether, $2: 3$ ) $=0.20 .-$ IR (neat): $\check{v}=3550-3250$ $(\mathrm{OH}, \mathrm{NH}), 1600 \mathrm{~cm}^{-1}(\mathrm{C}=\mathrm{C}) .-{ }^{1} \mathrm{H}$ NMR $\left(\mathrm{CDCl}_{3}\right): \delta=1.72(\mathrm{~s} ;$ $3 \mathrm{H}, \mathrm{CH}_{3}$ ), 3.61 (s; $2 \mathrm{H}, \mathrm{CH}_{2}$ ), 6.18 (br.; $1 \mathrm{H}, \mathrm{NH}$ ), 6.62 (dd, $J_{1}=$ $7.5 \mathrm{~Hz}, J_{2}=1 \mathrm{~Hz} ; 2 \mathrm{H}, 4-\mathrm{H}$ and $5-\mathrm{H}$ ), 6.94 and 7.14 (A and B part of an $\mathrm{ABMN}$ system; $J_{\mathrm{AB}}=7.5 \mathrm{~Hz}, J_{\mathrm{AM}}=J_{\mathrm{BN}}=7.5 \mathrm{~Hz}, J_{\mathrm{AN}}=$ $J_{\mathrm{BM}}=1 \mathrm{~Hz} ; 4 \mathrm{H}, 2-\mathrm{H}, 3-\mathrm{H}, 6-\mathrm{H}$ and $\left.7-\mathrm{H}\right), 7.37\left(\mathrm{ddd}, J_{1}=7.5 \mathrm{~Hz}\right.$, $J_{2}=1 \mathrm{~Hz}, J_{3}=0.5 \mathrm{~Hz} ; 2 \mathrm{H}, 1-\mathrm{H}$ and $\left.8-\mathrm{H}\right) .-{ }^{13} \mathrm{C} \mathrm{NMR}\left(\mathrm{CDCl}_{3}\right)$ : $\delta=22.86\left(\mathrm{CH}_{3}\right), 42.41(\mathrm{C}-9), 70.91\left(\mathrm{CH}_{2} \mathrm{OH}\right), 113.62,120.41,126.45$ and 127.36 (arom. CH), 124.02 and 139.31 (arom. C). - MS (70 eV): $m / z(\%)=225(9)\left[\mathrm{M}^{+}\right], 194(100)\left[\mathrm{M}^{+}-\mathrm{CH}_{2} \mathrm{OH}\right]$.

$$
\begin{array}{ll}
\mathrm{C}_{15} \mathrm{H}_{15} \mathrm{NO} \text { (225.3) } & \text { Calcd. C } 79.97 \text { H } 6.71 \\
& \text { Found C } 79.78 \text { H } 6.76
\end{array}
$$

9-Hydroxymethyl-9-phenyl-9,10-dihydroacridine (9b): From $2.90 \mathrm{~g}$ (6.2 mmol) of $8 \mathrm{~b}, 1.34 \mathrm{~g}(75 \%) 9 \mathrm{~b}$ was obtained after flash chromatography on silica gel $(90 \mathrm{~g})$. $-R_{\mathrm{f}}$ (diethyl ether/petroleum ether, $1: 1)=0.35$. - M.p. $159-160^{\circ} \mathrm{C}$ - IR $(\mathrm{KBr}): \hat{v}=3510(\mathrm{OH})$, $3310(\mathrm{NH}), 1600 \mathrm{~cm}^{-1}(\mathrm{C}=\mathrm{C}) .-{ }^{1} \mathrm{H}$ NMR $\left(\mathrm{CDCl}_{3}\right): \delta=1.56(\mathrm{~b}$; $1 \mathrm{H}, \mathrm{OH}), 4.10\left(\mathrm{~s} ; 2 \mathrm{H}, \mathrm{CH}_{2} \mathrm{OH}\right), 6.31$ (br.; $\left.1 \mathrm{H}, \mathrm{NH}\right), 6.68-7.49(\mathrm{~m}$; $13 \mathrm{H}$, arom. H). $-{ }^{13} \mathrm{C} \mathrm{NMR}\left(\mathrm{CDCl}_{3}\right): \delta=52.27$ (C-9), 68.09 $\left(\mathrm{CH}_{2} \mathrm{OH}\right), 113.38,120.37,126.27,127.59,127.93,129.84$ and 129.95 (arom. CH), 124.42, 138.72 and 146.13 (arom. C). - MS (70 eV): $m / z(\%)=287(34)\left[\mathrm{M}^{+}\right], 257(97)\left[\mathrm{M}^{+}-\mathrm{CH}_{2} \mathrm{OH}+\mathrm{H}\right], 256$ (100) $\left[\mathrm{M}^{+}-\mathrm{CH}_{2} \mathrm{OH}\right], 255$ (53) $\left[\mathrm{M}^{+}-\mathrm{CH}_{2} \mathrm{OH}\right], 254$ (80) $\left[\mathrm{M}^{+}-\mathrm{CH}_{2} \mathrm{OH}-2 \mathrm{H}\right]$.

$$
\mathrm{C}_{20} \mathrm{H}_{17} \mathrm{NO} \text { (287.4) Calcd. C } 83.60 \text { H } 5.96
$$

9-(1'-Hydroxybenzyl)-9-phenyl-9,10-dihydroacridine (9c): To a solution of $8 \mathrm{c}(1.59 \mathrm{~g}, 3.5 \mathrm{mmol})$ in THF $(40 \mathrm{ml})$ and $\mathrm{NH}_{3}(80 \mathrm{ml})$, lithium pellets $(0.12 \mathrm{~g}, 17.2 \mathrm{mmol})$ were added at $-70^{\circ} \mathrm{C}$. The dark blue solution was stirred for $2 \mathrm{~h}$ at $-70^{\circ} \mathrm{C}$. Then a solution of acetic acid $(1.5 \mathrm{ml})$ in THF $(5 \mathrm{ml})$ was added, and the ammonia and the solvent were removed in vacuo. The residue was dissolved in diethyl ether $(50 \mathrm{ml})$ and the solution washed with $30-\mathrm{ml}$ portions of water and a saturated $\mathrm{NaCl}$ solution. The combined aqueous layers were reextracted twice with diethyl ether $(30 \mathrm{ml})$, the combined organic layers were dried with $\mathrm{MgSO}_{4}$ and the solvent was removed in vacuo. The crude product was purified by flash chromatography on silica gel $(60 \mathrm{~g})$ to yield the sensitive amino alcohol $9 \mathrm{c}(0.54 \mathrm{~g}, 42 \%)$ as a yellow oil. $0.32 \mathrm{~g}(0.7 \mathrm{mmol})$ of the starting material $8 \mathrm{c}$ was recovered. - $R_{\mathrm{f}}$ (diethyl ether/petroleum ether, $1: 5)=0.30 .-$ IR (neat): $\tilde{v}=3520(\mathrm{OH}), 3400(\mathrm{NH}), 1600 \mathrm{~cm}^{-1}$ $(\mathrm{C}=\mathrm{C}) .-{ }^{1} \mathrm{H} \mathrm{NMR}\left(\mathrm{CDCl}_{3}\right): \delta=2.32(\mathrm{~d}, J=6 \mathrm{~Hz} ; 1 \mathrm{H}, \mathrm{OH})$, $5.46(\mathrm{~d}, J=6 \mathrm{~Hz} ; 1 \mathrm{H}, \mathrm{PhCHOH}), 5.53(\mathrm{~s} ; 1 \mathrm{H}, \mathrm{NH}), 6.11-7.71(\mathrm{~m}$; $18 \mathrm{H}$, arom. H). $-{ }^{13} \mathrm{C} \mathrm{NMR}\left(\mathrm{CDCl}_{3}\right): \delta=56.28(\mathrm{C}-9), 78.92$ (PhCHOH), 112.65, 112.86, 119.15, 119.64, 125.88, 126.55, 127.01, $127.09,127.28,127.70,127.78,130.25,130.72$ and 132.45 (arom. $\mathrm{CH}$ ), $120.90,125.03,138.11,139.74,140.68$ and 148.33 (arom. C). - MS $(70 \mathrm{eV}): m / z(\%)=256(100)\left[\mathrm{M}^{+}-\mathrm{PhCHOH}\right]$.

Preparation and Reactions of the Mesylates 1 with Potassium tertButoxide/DMSO. - Compounds 5, 10, 11. - General Procedure: a) To a stirred solution of the amino alcohols $9 \mathbf{a}-\mathbf{c}$ in dichloromethane $(15 \mathrm{ml})$ were added 1.1 equivalents of methanesulfonyl chloride and 1.1 equivalents of triethylamine at $0^{\circ} \mathrm{C}$. The reaction mixture was stirred for $15 \mathrm{~min}$ at $0 . \mathrm{C}$ and for $2 \mathrm{~h}$ at $25^{\circ} \mathrm{C}$. The crude mixture was washed with $15-\mathrm{ml}$ portions of $0.1 \mathrm{~N} \mathrm{HCl}, 10 \%$ $\mathrm{NaHCO}_{3}$ and saturated $\mathrm{NaCl}$ solution, and the united aqueous layers were reextracted twice with dichloromethane $(15 \mathrm{ml})$. The combined organic layers were dried with $\mathrm{MgSO}_{4}$, and the solvent was removed in vacuo. In order to avoid decomposition, the sensitive mesylates 1 were directly submitted to reaction with potassium tert-butoxide/DMSO without further purification.

b) To a solution of 1.1 equivalents of potassium tert-butoxide in DMSO $(10 \mathrm{ml})$, a solution of crude mesylates 1 in DMSO $(10 \mathrm{ml})$ was added. Stirring was continued for $30 \mathrm{~min}$. Then water $(80 \mathrm{ml})$, $10 \% \mathrm{NaHCO}_{3}(20 \mathrm{ml})$ and diethyl ether $(50 \mathrm{ml})$ were added. The layers were separated, and the aqueous layer was reextracted four times with $40 \mathrm{ml}$ portions of diethyl ether. The combined organic layers were washed with a saturated $\mathrm{NaCl}$ solution $(100 \mathrm{ml})$ and dried with $\mathrm{MgSO}_{4}$. The solvent was removed in vacuo, and the residue was purified by flash chromatography.

10-Methylidene-5H,11H-dibenzo [a,d] azepine (10): From $0.60 \mathrm{~g}$ $(2.66 \mathrm{mmol})$ of the amino alcohol $9 \mathrm{a}, 0.34 \mathrm{~g}(2.97 \mathrm{mmol})$ of methanesulfonyl chloride, $0.30 \mathrm{~g}$ ( $2.97 \mathrm{mmol})$ of triethylamine and $0.33 \mathrm{~g}$ $(2.94 \mathrm{mmol})$ of potassium tert-butoxide in the subsequent reaction $0.35 \mathrm{~g}(63 \%)$ of 10 was obtained as a light yellow oil after flash chromatography on silica gel $(40 \mathrm{~g})$. $-R_{\mathrm{f}}$ (petroleum ether/diethyl ether/triethylamine, $100: 10: 1)=0.35$ - IR $(\mathrm{KBr}): \dot{v}=3370$ $(\mathrm{NH}), 1605(\mathrm{C}=\mathrm{C}), 1580 \mathrm{~cm}^{-1}(\operatorname{arom}, \mathrm{C}=\mathrm{C}) .-{ }^{1} \mathrm{H} \mathrm{NMR}\left(\mathrm{CDCl}_{3}\right)$ : $\delta=3.67\left(\mathrm{~s} ; 2 \mathrm{H}, 11-\mathrm{CH}_{2}\right), 4.92$ and $5.26(2 \mathrm{~d}, J=1.5 \mathrm{~Hz}, 1 \mathrm{H}$, exo$\left.\mathrm{CH}_{2}\right), 6.12$ (br.; $\left.1 \mathrm{H}, \mathrm{NH}\right), 6.70-7.42(\mathrm{~m} ; 8 \mathrm{H}$, arom. $\mathrm{H}) .-{ }^{13} \mathrm{C} \mathrm{NMR}$ $\left(\mathrm{CDCl}_{3}\right): \delta=43.17\left(\mathrm{CH}_{2}\right), 110.72\left(\mathrm{CH}_{2}\right), 117.96,118.16,118.68$ and 121.86 (arom. $\mathrm{CH}$ ), 126.04 (C-10), 126.77, 128.35, 128.43 and 129.21 
(arom. CH), 129.97, 140.43, 141.21 and 144.50 (arom. C). - MS $(70 \mathrm{eV}): m / z(\%)=207(100)\left[\mathrm{M}^{+}\right]$.

$$
\begin{array}{ll}
\mathrm{C}_{15} \mathrm{H}_{13} \mathrm{~N}(207.3) & \text { Calcd. C } 86.92 \text { H } 6.32 \\
& \text { Found C 86.82 H } 6.37
\end{array}
$$

Isomerization of 10. - 10-Methyl-5H-dibenzola,d]azepine (5a): $10(320 \mathrm{mg}, 1.54 \mathrm{mmol})$ and $p$-toluenesulfonic acid $(30 \mathrm{mg}, 0.16$ $\mathrm{mmol})$ were dissolved in toluene $(15 \mathrm{ml})$ and refluxed for $30 \mathrm{~min}$. The solution was washed with $10-\mathrm{ml}$ portions of $10 \% \mathrm{NaHCO}_{3}$ and saturated $\mathrm{NaCl}$ solution, and the aqueous layers were reextracted with toluene $(10 \mathrm{ml})$. The combined organic layers were dried with $\mathrm{MgSO}_{4}$, and the solvent was removed in vacuo. The crude product was purified by flash chromatography on silica gel $(30 \mathrm{~g})$ to yield $0.29 \mathrm{~g}(92 \%)$ of $\mathbf{5 a}$. $-R_{\mathrm{f}}$ (diethyl ether/petroleum ether, $1: 10)=0.21$ - M.p. $129^{\circ} \mathrm{C}$. - IR $(\mathrm{KBr}): \tilde{v}=3320(\mathrm{NH})$, $1600 \mathrm{~cm}^{-1}(\mathrm{C}=\mathrm{C}) .-{ }^{1} \mathrm{H}$ NMR $\left(\mathrm{CDCl}_{3}\right): \delta=1.85(\mathrm{~d}, J=1.5 \mathrm{~Hz}$; $\left.3 \mathrm{H}, \mathrm{CH}_{3}\right), 5.07$ (br.; $\left.1 \mathrm{H}, \mathrm{NH}\right), 6.56-6.72(\mathrm{~m} ; 3 \mathrm{H}, 11-\mathrm{H}$ and arom. $\mathrm{H}), 6.85-7.26\left(\mathrm{~m} ; 6 \mathrm{H}\right.$, arom. H). $-{ }^{13} \mathrm{C} \mathrm{NMR}\left(50.3 \mathrm{MHz}, \mathrm{CDCl}_{3}\right)$ : $\delta=24.63\left(\mathrm{CH}_{3}\right), 118.98,120.03,123.17,123.27,127.73,128.35$, 129.15, 129.58 and 129.99 (arom. CH and CH-11), 130.82, 132.55, 137.88, 148.44 and 149.23 (arom. C and C-10). - MS (70 eV): $m / z$ $(\%)=207(100)\left[\mathrm{M}^{+}\right]$.

$$
\begin{array}{ll}
\mathrm{C}_{15} \mathrm{H}_{13} \mathrm{~N} \text { (207.3) } & \text { Calcd. C } 86.92 \text { H } 6.32 \\
& \text { Found C } 86.77 \text { H } 6.26
\end{array}
$$

10-Phenyl-5H-dibenzo[a,d]azepine (5b): From $1.15 \mathrm{~g}$ ( $4.0 \mathrm{mmol})$ of the amino alcohol $9 \mathrm{~b}, 0.50 \mathrm{~g}(4.4 \mathrm{mmol})$ of methanesulfonyl chloride, $0.45 \mathrm{~g}(4.4 \mathrm{mmol})$ of triethylamine and $0.49 \mathrm{~g}(4.4 \mathrm{mmol})$ of potassium tert-butoxide in the subsequent reaction $0.70 \mathrm{~g}(65 \%)$ of 5b was obtained after flash chromatography on silica gel $(80 \mathrm{~g})$. $R_{\mathrm{f}}$ (diethyl ether/petroleum ether, $\left.1: 10\right)=0.19$. - M.p. $137^{\circ} \mathrm{C}$. IR $(\mathrm{KBr}): \tilde{v}=3320(\mathrm{NH}), 1565 \mathrm{~cm}^{-1}(\mathrm{C}=\mathrm{C}) .-{ }^{1} \mathrm{H} \mathrm{NMR}\left(\mathrm{CDCl}_{3}\right)$ : $\delta=5.14$ (br.; $1 \mathrm{H}, \mathrm{NH}), 6.65-7.42(\mathrm{~m} ; 14 \mathrm{H}$, arom. $\mathrm{H}$ and $11-\mathrm{H})$. ${ }^{13} \mathrm{C} \mathrm{NMR}\left(\mathrm{CDCl}_{3}\right): \delta=119.25,120.41,122.98,123.18,127.33$, $128.15,128.81,128.87,129.42,130.31,131.26$ and 131.33 (arom. $\mathrm{CH}$ and $\mathrm{CH}-11$ ), 129.87, 131.96, 143.78, 144.00, 149.04 and 149.97 (arom. $\mathrm{C}$ and $\mathrm{C}-10)$. - MS $(70 \mathrm{eV}): m / z(\%)=269(100)\left[\mathrm{M}^{+}\right]$.

$$
\mathrm{C}_{20} \mathrm{H}_{15} \mathrm{~N} \text { (269.4) Calcd. C } 89.19 \text { H } 5.61
$$

9-Phenylacridine: From $290 \mathrm{mg}$ ( $2.66 \mathrm{mmol})$ of the amino alcohol $9 \mathrm{c}, 100 \mathrm{mg}(0.88 \mathrm{mmol})$ of methanesulfonyl chloride, $89 \mathrm{mg}(0.88$ mmol) of triethylamine and $98 \mathrm{mg}(0.88 \mathrm{mmol})$ of potassium tertbutoxide in the subsequent reaction $82 \mathrm{mg}(40 \%)$ of 9-phenylacridine was obtained after flash chromatography on silica gel $(40 \mathrm{~g})$. $R_{\mathrm{f}}$ (diethyl ether/petroleum ether, $\left.1: 5\right)=0.20$. - M.p. $181^{\circ} \mathrm{C}$ (ref. ${ }^{[6]}$ m.p. $\left.184^{\circ} \mathrm{C}\right)$ - IR (KBr): $\tilde{v}=1600 \mathrm{~cm}^{-1}(\mathrm{C}=\mathrm{C}) .-{ }^{1} \mathrm{H}$ NMR $\left(\mathrm{CDCl}_{3}\right): \delta=7.36-7.85\left(\mathrm{~m} ; 11 \mathrm{H}\right.$, arom. $\mathrm{H}$ ), 8.30 (part of an $\mathrm{AA}^{\prime} \mathrm{BB}^{\prime}$ system, $J_{\mathrm{AB}}=9 \mathrm{~Hz} ; 2 \mathrm{H}$, arom. $\left.\mathrm{H}\right) .-{ }^{13} \mathrm{C} \mathrm{NMR}\left(\mathrm{CDCl}_{3}\right): \delta=$ $125.53,126.77,128.27,128.36,129.48,129.89$ and 135.83 (arom. $\mathrm{CH}$ ), 125.04, 135.83, 147.13 and 148.66 (arom. C). - MS (70 eV): $m / z$ $(\%)=255(100)\left[\mathrm{M}^{+}\right]$.

$\mathrm{C}_{19} \mathrm{H}_{13} \mathrm{~N}$ Calcd. 255.1048 Found 255.1048 [HRMS (70 eV)]

\section{CAS Registry Numbers}

5a: 92552-17-5 / 5b: 136947-27-8 / 6: 260-94-6 / 6 (9-Ph instead of H): 602-56-2 / 7a: 22776-69-8 / 7b: 102949-21-3/8a: 136947-21-2 / $\mathbf{8 b}: 136947-23-4 / 8 \mathbf{c}: 136947-24-5 / 9 \mathbf{a}: 1909-07-5 / 9 \mathbf{b}: 136947-$ 25-6 / 9c: $136947-26-7 / 10: 136947-22-3$

${ }^{[1]}$ U. Schöllkopf, J. Mittendorf, Angew. Chem. 1989, 103, 633-634; Angew. Chem. Int. Ed. Engl. 1989, 28, 613-614.

${ }^{[2]}$ For a similar kationic ring expansion see: [2a] N. A. Nelson, J. H. Fassnacht, J. U. Piper, J. Am. Chem. Soc. 1961, 83, 206-213. - ${ }^{\left[{ }^{2 b]}\right]}$ H. J. Dauben, D. J. Bertelli, J. Am. Chem. Soc. 1961, 83, 4657-4659.

${ }^{[3]}$ H. Kohn, J. D. Conley, Chem. Br. 1988, 231-234.

${ }^{[4]}$ F. Hoffmeister, G. Stille, Handb. Exp. Pharmacol. 1980, 55, (Psychotropic Agents, Part I).

[s] [sa] I. Fleming, Frontier Orbitals and Organic Chemical Reactions, Wiley, London 1976, p. $141-142 .-{ }^{[5 b]}$ L. Richter, Ph. D. Thesis, Univ. of Göttingen, 1991. - ${ }^{[5 c]}$ C. B. Argo, J. T. Sharp, J. Chem. Soc., Perkin Trans. 1, 1984, $1581-1587$. - [5d] J. R. de Dobbelaere, J. M. F. van Dijk, J. W. de Haan, H. M. Buck, $J$. Am. Chem. Soc. 1977, 99, 392-397.

${ }^{[6]}$ A. Albert, The Acridines, 2nd ed., E. Arnold Publishers Ltd., London, 1966.

$[206 / 91]$ 